\title{
Medical specialists in Mexico
}

Gerhard Heinze-Martin, Víctor Hugo Olmedo-Canchola, Germán Bazán-Miranda, Napoléon Andrés Bernard-Fuentes and Diana Patricia Guízar-Sánchez

Universidad Nacional Autónoma de México, Division of Postgraduate Studies, Faculty of Medicine, Ciudad de México, Mexico

\begin{abstract}
Introduction: There are no recent data in Mexico about the state of medical specialists that allow the design of policies for training and use of human resources for health. Objective: To analyze the current state of medical specialists in Mexico: number, distribution (geographical, by gender and specialty), certification validity (by gender and specialty) and the rate of specialists per 100000 population. Method: Cross-sectional, descriptive study. Multiple sources available in Mexico were consulted: councils, associations, schools, hospital institutions, universities, and others. Results: $A$ total of 147,910 specialists were counted for a total population of 123,518,272 inhabitants; $69 \%$ had current specialty certification. A rate of 119 specialists per 100000 population was obtained; $54.2 \%$ are in Mexico City and in the States of Mexico, Jalisco and Nuevo León. On average, there are 1.7 male specialists per female specialist. Conclusions: The number of specialists is lower than that internationally recommended and insufficient to cover the health needs of the country. Gender distribution is shifting towards a more equitable one. Specialists are mainly grouped in urban areas. This is the first census of specialists based on total verifiable number of physicians, which will allow the design of policies for human resources planning in health.
\end{abstract}

KEY WORDS: Medical specialists. Human resources in health. Certified specialists. Mexico.

\section{Introduction}

World Health Organization (WHO) 2015 statistics refer that there are 139 physicians per 100000 popu-

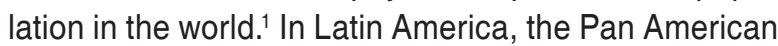
Health Organization (PAHO) suggests there are 176 physicians per 100000 population. $^{2}$ In Mexico, according to the last census carried out in 2011 by the National Institute of Statistics, Geography and Informatics, there were 157 doctors per 100000 population. ${ }^{3}$ The number of physicians per capita has increased from 160 per 100000 in 2000 to 220 in 2014;, however, it is still below the average of 320 in countries belonging to the Organization for Economic Cooperation and Development (OECD). ${ }^{4}$ In 2015, the OECD reported the existence of more medical specialists (MS) than primary care physicians (PCP) and family doctors (65 versus $35 \%$, respectively), ${ }^{4}$ a similar figure than that of other OECD countries, such as the
United Kingdom (MS $=71.4 \%$ versus PCP $=28.6 \%)$, but contrasting with those of Chile (MS $=51.8 \%$ versus $\mathrm{PCP}=48.2 \%)$ and France (MS $=49.8 \%$ versus $\mathrm{PCP}=50.2 \%$ ).

The Inter-institutional Commission for the Training of Human Resources for Health (CIFRHS - Comisión Interinstitucional para la Formación de Recursos Humanos para la Salud), through the Post-degree Committee, is the coordinating agency of the National Exam for Medical Residence Aspirants (ENARM - Examen Nacional para Aspirantes a las Residencias Médicas). In 2016, 38077 general physicians contested for the 7805 available posts to start specialization training. ${ }^{5}$ The National Health System has 81 specialty courses available,$^{5}$ out of which 78 are offered by the National Autonomous University of Mexico (UNAM - Universidad Nacional Autónoma de México). ${ }^{6}$

According to Zurn et al., in the Mexican health system there are 5 types of evident inequities:
Correspondence:

Diana Patricia Guízar-Sánchez

E-mail: guizar.diana@comunidad.unam.mx
Date of reception: 06-10-2017

Date of acceptance: 25-01-2018

DOI://dx.doi.org/10.24875/GMM.M18000152
Gac Med Mex. 2018;154:281-289

Contents available at PubMed www.gacetamedicademexico.com 
geographical, by gender, in the relationship of general physicians and specialists, in public and private care, as well as institutional and per departments.

To the extent covered by this review, there are no recent data in Mexico on MS current status whereby to design and promote new policies on training and use of human resources for health. There is only one study by Heinze et al., ${ }^{8}$ where challenges are laid out on the number, distribution (geographic and gender-wise) and certification validity of a single medical specialty (psychiatry).

\section{Objective}

To know total number of medical specialists in Mexico, their distribution (geographical and by gender and specialty), the percentage with valid certification (by gender and specialty); to estimate the rate of specialists per 100000 population (whether it is in accordance with health requirements) and to establish a comparison with international standards, and thereby indirectly assessing specialists' current status in Mexico.

\section{Method}

A descriptive, cross-sectional study was carried out by consulting the records of the General Directorate of Professions of the Ministry of Public Education, the records of the different councils belonging to the $\mathrm{Na}$ tional Regulatory Committee of Medical Specialty Councils (CONACEM - Comité Normativo Nacional de Consejos de Especialidades Médicas), databases of the different colleges, societies or associations of each specialty, records of institutes and hospitals with posts to practice or study the different medical specialties (Mexican Institute of Social Security, Institute of Social Security and Services for State Workers, Petróleos Mexicanos and the Ministry of Health) and the directories of health insurance companies. These sources were taken into account because they are regarded as the most reliable for data obtainment; the response rate was higher than $90 \%$. The database was reviewed, corrected and validated. In addition to total number of medical specialists, their distribution by gender was obtained and the percentage of certified specialists was calculated.

With National Council of Population data, ${ }^{9}$ the rate of specialists per 100000 population was determined, both in the country and by State. Those states where the number of specialists was below the average
Table 1. Medical specialists in 4 countries belonging to the Organization for Economic Cooperation and Development

\begin{tabular}{lccc}
\hline Country & Population & $\begin{array}{c}\text { Total } \\
\text { specialists } \\
\text { (n) }\end{array}$ & $\begin{array}{c}\text { Specialists/100 000 } \\
\text { population } \\
\text { (n) }\end{array}$ \\
\hline (n) & Total specialists & 130563 & 201 \\
(n) & $\begin{array}{l}\text { Specialists/100 } \\
\text { 000 population }\end{array}$ & 120107 & 181 \\
(n) & 123518272 & 147910 & 119 \\
Chile & 18121818 & 19934 & 110 \\
\hline $\begin{array}{l}\text { Created based on available information: http://stats.oecd.org//ndex.aspx? } \\
\text { DataSetCode=HEALTH_REACH.4 }\end{array}$ & & $\frac{-}{5}$ \\
\end{tabular}

recommended by international organizations were determined.

This investigation was approved by the Committee of Research and Ethics of the UNAM Faculty of Medicine, with the results being presented according to the 78 specialties offered in this institution.

\section{Results}

In 2017, 147910 medical specialists practiced their profession in Mexico (37.4\% of women and $62.6 \%$ of men). Table 1 shows a comparison with other OECD countries. ${ }^{4}$ Gender ratio was 1.7 males per one female, and it varied depending on the specialty (Table 2). On average, $69 \%$ had certification validated by the medical council of the respective specialty $(73.5 \%$ of females versus $64.5 \%$ of males) at the moment of the study. Gynecologic urology (97.5\%) and reproductive biology $(97.4 \%)$ were the specialties with the highest number of MS with valid certification, while occupational medicine $(20.2 \%)$ and neuropathology $(9.5 \%)$ were the specialties with the lowest percentages (Table 3).

With regard to geographical distribution, $54.2 \%$ of medical specialists were concentrated in Mexico City, State of Mexico, Jalisco and Nuevo León; the remaining $45.8 \%$ of MS were found to be distributed in the other 28 States. Of the 32 federal entities of the Mexican Republic, Mexico City had the highest rate of medical specialists (505.7/100 000 population), followed by Nuevo León (185.3/100 000 population) and Jalisco (172/100 000 population) (Fig. 1). The lowest rates were shown by Chiapas (35.9/100 000 population), Guerrero (39.2/100 000 population) and Tlaxcala (51.7/100 000 population).

Table 4 shows the nation-wide estimated rate (per 100000 population) of the 30 medical specialties with the highest number of professionals, where an important contrast was observed, with specialties such as 
Table 2. Specialties with higher contrast in the male/female ratio

\begin{tabular}{lclc}
\hline Specialties with higher number of males & M:F ratio & Specialties with higher number of females & M/F ratio \\
\hline Urology & $45: 1$ & Pediatric dermatology & $4: 1$ \\
Neurosurgery & $18: 1$ & Audiology, otoneurology and speech therapy & $3: 1$ \\
Orthopedics and traumatology & $14: 1$ & Pediatric hematology & $3: 1$ \\
Adult oncological surgery & $10: 1$ & Pediatric endocrinology & $2: 1$ \\
Cardiothoracic surgery & $10: 1$ & Dermatology & $2: 1$ \\
\hline
\end{tabular}

\begin{tabular}{|c|c|c|c|}
\hline State & $\begin{array}{c}\text { Population } \\
\text { (inhabitants) }\end{array}$ & $\begin{array}{c}\text { Number of medical } \\
\text { specialists }\end{array}$ & Rate \\
\hline CDMX & 8811266 & 44562 & 505.7 \\
\hline Nuevo León & 5229492 & 9689 & 185.3 \\
\hline Jalisco & 8110943 & 13950 & 172.0 \\
\hline Yucatán & 2172839 & 2934 & 135.0 \\
\hline Querétaro & 2063148 & 2449 & 118.7 \\
\hline San Luis Potosí & 2801839 & 3191 & 113.9 \\
\hline Aguascalientes & 1321453 & 1484 & 112.3 \\
\hline Baja California & 3584605 & 3692 & 103.0 \\
\hline Sonora & 3011810 & 2882 & 95.7 \\
\hline Durango & 1799320 & 1718 & 95.5 \\
\hline Morelos & 1965487 & 1865 & 94.9 \\
\hline Coahuila & 3029740 & 2854 & 94.2 \\
\hline Sinaloa & 3034942 & 2802 & 92.3 \\
\hline Colima & 747801 & 684 & 91.5 \\
\hline Campeche & 935047 & 854 & 91.3 \\
\hline BCS & 809833 & 736 & 90.9 \\
\hline Nayarit & 1268460 & 1152 & 90.8 \\
\hline Tamaulipas & 3622605 & 3213 & 88.7 \\
\hline Chihuahua & 3782018 & 3298 & 87.2 \\
\hline Puebla & 6313789 & 5443 & 86.2 \\
\hline Guanajuato & 5908845 & 4924 & 83.3 \\
\hline Tabasco & 2431339 & 1941 & 79.8 \\
\hline Quintana Roo & 1664667 & 1234 & 74.1 \\
\hline Hidalgo & 2947206 & 2178 & 73.9 \\
\hline Michoacán & 4658159 & 3269 & 70.2 \\
\hline Edo. Mex & 17363387 & 11997 & 69.1 \\
\hline Veracruz & 8163963 & 5295 & 64.9 \\
\hline Oaxaca & 4061497 & 2602 & 64.1 \\
\hline Zacatecas & 1600412 & 991 & 61.9 \\
\hline Tlaxcala & 1313067 & 679 & 51.7 \\
\hline Guerrero & 3607210 & 1414 & 39.2 \\
\hline Chiapas & 5382083 & 1934 & 35.9 \\
\hline
\end{tabular}

Figure 1. Distribución de ME por entidad federativa. Tasa por 100000 habitantes. neonatology, with 76.7 (MS/100 000 population), while others such as nephrology have less than one (MS/100 000 population).

\section{Discussion}

Currently, the demand for medical specialists is a subject of constant discussion and debate. Gaps corresponding to the distance between what is needed and what is offered are pointed out. The generation of human resources for health in adequate amounts and with appropriate characteristics is one of the basic functions of health systems. With the present work, the following challenges are identified:

- Number of MS not according to migration, population aging and chronic-degenerative diseases transition.

- Inequitable geographical distribution of specialists in the country.

- Specialties with less than $50 \%$ of physicians with valid certification, even when since 2011 it is a requirement for the specialist license to be issued by the Ministry of Public Education (article 81 of the General Statute of Health) ${ }^{11}$ and CONACEM establishes validity renewal every 5 years.

With regard to medical specialists' total number, it is necessary for the planning process for their training to be comprehensively reviewed.

As for general medical training, it should be pointed out that, in Mexico, more physicians graduate every year than the average of countries that belong to the OECD (12 versus 10 per 100000 population, respectively). ${ }^{4}$ Mexico is one of the countries with higher number of medical schools: ${ }^{12}$ according to the Education Official Validity Recognition ${ }^{13}$ of the Ministry of Public Education, currently there are 160 medical schools in the country, out of which only 70 are certified by the Mexican Council for Medical Education Certification 
Gaceta Médica de México. 2018;154

Table 3. Total hombres y mujeres especialistas con certificación vigente

\begin{tabular}{|c|c|c|c|c|c|c|}
\hline Specialty & $\begin{array}{c}\text { Male } \\
\text { specialists }(n)\end{array}$ & $\begin{array}{c}\text { Males } \\
\text { with valid } \\
\text { certification } \\
\text { (\%) }\end{array}$ & $\begin{array}{c}\text { Female } \\
\text { specialists (n) }\end{array}$ & $\begin{array}{c}\text { Females } \\
\text { with valid } \\
\text { certification } \\
\text { (\%) }\end{array}$ & $\begin{array}{c}\text { Total } \\
\text { specialists }(n)\end{array}$ & $\begin{array}{c}\text { Specialists } \\
\text { with valid } \\
\text { certification (\%) }\end{array}$ \\
\hline $\begin{array}{l}\text { Allergy and immunology } \\
\text { (adult and pediatric) }\end{array}$ & 633 & 52.7 & 482 & 54.5 & 1115 & 53.6 \\
\hline Anatomic pathology & 779 & 62.2 & 732 & 57.1 & 1511 & 59.7 \\
\hline $\begin{array}{l}\text { Anesthesiology (adult, pediatric and } \\
\text { neuroanesthesiology) }\end{array}$ & 7889 & 43.9 & 6565 & 56.4 & 14454 & 50.4 \\
\hline Angiology and vascular surgery & 500 & 49.8 & 106 & 80.1 & 606 & 55.1 \\
\hline $\begin{array}{l}\text { Audiology, otoneurology and speech } \\
\text { therapy }\end{array}$ & 151 & 60.2 & 464 & 74.1 & 615 & $\begin{array}{r}70.7 \\
\underline{0}\end{array}$ \\
\hline Human reproductive biology & 151 & 96.6 & 86 & 98.8 & 237 & 97.4 \\
\hline Cardiology (adult and pediatric) & 2473 & 70.25 & 519 & 73.1 & 2992 & 70.7 \\
\hline $\begin{array}{l}\text { Cardiothoracic surgery (adult and } \\
\text { pediatric) }\end{array}$ & 394 & 79.4 & 40 & 90.5 & 434 & 80.8 \\
\hline General surgery & 9714 & 34.3 & 1268 & 47.4 & 10982 & 35.8 \\
\hline Pediatric surgery & 874 & 65.8 & 166 & 84.9 & 1040 & 68.8 \\
\hline Surgical oncology & 794 & 95.4 & 82 & 89.9 & 876 & 94.8 \\
\hline Plastic and reconstructive surgery & 1550 & 86.3 & 266 & 85.7 & 1816 & 86.4 \\
\hline Coloproctology & 397 & 71.8 & 64 & 68.8 & 461 & 71.3 \\
\hline $\begin{array}{l}\text { Dermatology (adult, pediatric and } \\
\text { dermopathology) }\end{array}$ & 620 & 60.6 & 1164 & 90.6 & 1784 & $\stackrel{82.1}{\rightleftarrows}$ \\
\hline Endocrinology (adult and pediatric) & 675 & 57.7 & 644 & 61.9 & 1319 & 61 \\
\hline Epidemiology & 430 & 58.9 & 259 & 93.1 & 689 & 75.9 \\
\hline $\begin{array}{l}\text { Gastroenterology } \\
\text { (adult and pediatric) }\end{array}$ & 827 & 79.8 & 458 & 72.2 & 1285 & 74.3 \\
\hline Medical genetics & 107 & 71 & 181 & 91.7 & 288 & 84 \\
\hline Gynecologic oncology & 237 & 95.7 & 185 & 96.2 & 422 & 95.9 \\
\hline Obstetrics and gynecology & 91 & 98 & 60 & 95 & 151 & 97.3 \\
\hline Hematology (adult and pediatric) & 9654 & 36 & 6035 & 50.6 & 15689 & 41.6 \\
\hline Diagnostic-therapeutic imaging & 310 & 95.3 & 350 & 93.1 & 660 & 90.9 \\
\hline Infectology & 2282 & 92.1 & 1537 & 89.5 & 3819 & 91 \\
\hline $\begin{array}{l}\text { Critical medicine (adult and } \\
\text { pediatric) }\end{array}$ & 391 & 49.6 & 204 & 75 & 595 & $\stackrel{58.3}{0}$ \\
\hline $\begin{array}{l}\text { Physical activity and sports } \\
\text { medicine }\end{array}$ & 1285 & 44.1 & 644 & 52.4 & 1929 & $\begin{array}{c}4 \overline{7.4} \\
\overline{0}\end{array}$ \\
\hline Family medicine & 115 & 93 & 47 & 89.3 & 162 & 91.9 \\
\hline Internal medicine & 7831 & 27.6 & 9064 & 44.5 & 16895 & 36.7 \\
\hline Rehabilitation medicine & 7123 & 29.8 & 2778 & 39.8 & 9901 & 32.7 \\
\hline $\begin{array}{l}\text { Emergency medicine (adult and } \\
\text { pediatric) }\end{array}$ & 680 & 46 & 1156 & 70.3 & 1836 & 61.3 \\
\hline
\end{tabular}


Table 3. Total hombres y mujeres especialistas con certificación vigente (continued)

\begin{tabular}{|c|c|c|c|c|c|c|}
\hline Specialty & $\begin{array}{c}\text { Male } \\
\text { specialists }(n)\end{array}$ & $\begin{array}{c}\text { Males } \\
\text { with valid } \\
\text { certification } \\
\text { (\%) }\end{array}$ & $\begin{array}{c}\text { Female } \\
\text { specialists }(n)\end{array}$ & $\begin{array}{c}\text { Females } \\
\text { with valid } \\
\text { certification } \\
(\%)\end{array}$ & $\begin{array}{c}\text { Total } \\
\text { specialists (n) }\end{array}$ & $\begin{array}{c}\text { Specialists } \\
\text { with valid } \\
\text { certification (\%) }\end{array}$ \\
\hline Forensic medicine & 1387 & 72.7 & 1186 & 69.2 & 2573 & 73.5 \\
\hline Maternal-fetal medicine & 201 & 74.1 & 126 & 75.4 & 327 & 74.6 \\
\hline Nuclear medicine & 132 & 51.5 & 119 & 89 & 251 & 69.3 \\
\hline Occupational medicine & 142 & 80.9 & 79 & 84.8 & 221 & 82.3 \\
\hline Nephrology (adult and pediatric) & 833 & 18.5 & 453 & 23.4 & 1286 & 20.2 \\
\hline Neonatology & 694 & 89.5 & 423 & 97.5 & 1117 & 93.9 \\
\hline Pulmonology (adult and pediatric) & 743 & 60 & 973 & 67.4 & 1716 & 64.2 \\
\hline Neurosurgery & 720 & 76.5 & 351 & 96.1 & 1071 & 83 \\
\hline $\begin{array}{l}\text { (adult, pediatric and neurological } \\
\text { endovascular therapy) }\end{array}$ & 1076 & 71.9 & 70 & 89.9 & 1146 & 73.3 \\
\hline Clinical neurophysiology & 83 & 72.3 & 52 & 90.3 & 135 & 79.2 \\
\hline Neurology (adult and pediatric) & 906 & 49.5 & 439 & 68.3 & 1345 & 54.8 \\
\hline Neuropathology & 13 & 7.7 & 8 & 12.5 & 21 & 9.5 \\
\hline Neuroradiology & 75 & 48 & 28 & 32.1 & 103 & 43.7 \\
\hline Clinical nutrition & 49 & & 74 & & 123 & 흠 \\
\hline $\begin{array}{l}\text { Ophthalmology and neurological } \\
\text { ophthalmology }\end{array}$ & 2649 & 61 & 1782 & 71.5 & 4431 & 65.2 \\
\hline $\begin{array}{l}\text { ORL and head and neck surgery } \\
\text { (adult, pediatric and neurotology) }\end{array}$ & 1675 & 82.7 & 1064 & 83.8 & 2739 & 83.1 \\
\hline $\begin{array}{l}\text { Medical oncology } \\
\text { (adult and pediatric) }\end{array}$ & 331 & 87.2 & 279 & 88.4 & 610 & 86.7 \\
\hline Orthopedics and traumatology & 6775 & 48.3 & 481 & 53 & 7256 & 48.5 \\
\hline $\begin{array}{l}\text { Clinical pathology } \\
\text { (adult and pediatric) }\end{array}$ & 445 & 46.9 & 313 & 61.9 & 758 & 53.2 \\
\hline Pediatrics & 9499 & 47.6 & 9272 & 64.1 & 18771 & 55.8 \\
\hline Psychiatry (adult and pediatric) & 2836 & 35.2 & 1593 & 38.5 & 4429 & 35.1 \\
\hline Radio-oncology & 167 & 94.6 & 71 & 98.5 & 238 & 95.7 \\
\hline Rheumatology (adult and pediatric) & 521 & 56.4 & 379 & 73.3 & 900 & 78.4 \\
\hline Urology & 1663 & 68.2 & 37 & 81 & 1700 & 68.5 \\
\hline Urogynecology & 44 & 95.4 & 36 & 97.2 & 80 & 97.5 \\
\hline
\end{tabular}

(http://www.comaem.org.mx/), without a national policy in place to regulate the number of new students, the training quality or for such increase to respond to a strategic planning according to the epidemiological and demographic needs of the States or the country. On the other hand, the medical degree is often seen as paperwork that is necessary to become a specialist rather than an option of professional practice.
With regard to the number of specialists, in spite of the important graduation of general physicians in Mexico, the rate of specialists is lower than the average in other countries (178 versus 119 per 100 000population) ${ }^{4}$ higher than that in countries such as Chile (119), but lower than that in the United Kingdom (201) and France (181). It would be important for the differences in the planning for specialists to be assessed: 
Table 4. Medical specialists in Mexico per 100000 population $^{12}$

\begin{tabular}{|c|c|}
\hline Specialty & Rate per 100000 \\
\hline Neonatology* & 76.71 \\
\hline Pediatrics ${ }^{\star *}$ & 49.55 \\
\hline Obstetrics and gynecology ${ }^{\dagger}$ & 30.33 \\
\hline Family medicine & 14.08 \\
\hline Anesthesiology & 11.51 \\
\hline General surgery & 8.89 \\
\hline Internal medicine & 8.02 \\
\hline Orthopedics and traumatology & 5.87 \\
\hline Ophthalmology & 3.56 \\
\hline Psychiatry & 3.4 \\
\hline Geriatrics $^{\dagger \dagger}$ & 3.25 \\
\hline Diagnostic and therapeutic imaging & 3.09 \\
\hline Pediatric surgery* & 2.75 \\
\hline Cardiology & 2.16 \\
\hline Otorhinolaryngology and head and neck surgery & 2.08 \\
\hline Rehabilitation medicine & 1.49 \\
\hline Plastic and reconstructive surgery & 1.47 \\
\hline Urology & 1.38 \\
\hline Emergency medicine & 1.25 \\
\hline Endocrinology & 0.80 \\
\hline Maternal-fetal medicine ${ }^{\ddagger}$ & 0.73 \\
\hline Nephrology & 0.72 \\
\hline Surgical oncology & 0.71 \\
\hline Pulmonology & 0.69 \\
\hline Human reproduction biology ${ }^{\ddagger}$ & 0.69 \\
\hline Pediatric oncology* & 0.60 \\
\hline Epidemiology & 0.56 \\
\hline Infectology & 0.48 \\
\hline Medical oncology & 0.31 \\
\hline Gynecologic oncology ${ }^{\dagger}$ & 0.29 \\
\hline
\end{tabular}

Rate calculated based on births. ${ }^{10}$

'Rate calculated based on 0 to 16 -year population. ${ }^{10}$

thate calculated based on female population older than 10 years. ${ }^{10,1}$

"Rate calculated based on population older than 60 years. ${ }^{10}$

${ }^{\ddagger}$ Rate calculated based on child-bearing age female population.

- United Kingdom: Decentralized planning at the local and regional levels through the National Council for the Development of Health Personnel, which analyzes the demands and needs for specialized personnel and training of specialists, in a consistent manner with the approach that prevails in the European Union. ${ }^{14}$

- France: The Ministry of Higher Education and the Ministry of Health determine the list of available specialties, depending on the needs in terms of health and health research; the French government adjusts the number of provisions proposed by said ministries for each specialty in coordination with the different committees and ateas of the Faculty of Medicine..$^{15}$

- Mexico: Health institutions submit every year the available number of residence posts for each specialty to the CIFHRS, which takes care for the ENARM planning. After having passed the exam, the residents are assigned to the available positions according to their score. ${ }^{14}$

- Chile: A methodology that considers the available workforce was developed, thereby estimating the number of specialists that are required. The responsible for planning is the Ministry of Health together with the universities of the country that have programs for the training of medical specialists. ${ }^{14}$

It is important for the number of specialties that are recognized in a country to be analyzed, since the more specialties or specialty nomenclatures there are, the higher their deficit will be. A review of the medical-surgical specialty programs in Latin America refers a large difference in the number of recognized specialties, which ranges from 6 (El Salvador) to 82 (Colombia). ${ }^{16}$ In turn, the American Association of Medical Colleges (https://www.aamc.org/), on its specialty aspirants report, refers 45 specialties, which is a similar number than that in Costa Rica and Argentina, ${ }^{16}$ while the Ministry of Public Health, Social Services and Equality of Spain and the European Union of Medical Specialists report 50 medical specialties (https://www.uems.eu/).

Not only is it important for total number of specialties to be reviewed, but their increase has been inertial and bears no relation to population growth or modifications in the epidemiological profile, which hinders healthcare coverage adequate planning. ${ }^{17}$

In Mexico, non-communicable diseases have increased over the last 30 years: diabetes, chronic respiratory diseases, cardiovascular conditions, chronic kidney disease, ${ }^{17}$ liver disorders, musculoskeletal, mental health disorders (depression) and disability due to lumbar problems. ${ }^{18}$

In Mexico there is a larger number of pediatricians (49/100 000 children) and gynecologists (30/100 000 
women), in spite of the fertility rate having importantly been reduced (from 6.7 to 2.1 over the last 50 years). ${ }^{19}$ With regard to psychiatrists, even when mental disease represents $13 \%$ of disease global burden, ${ }^{20}$ in the country there are only 4195 psychiatrists, i.e., 3.4 per 100000 population (a figure that is lower than the $5 / 100000$ recommended by the WHO)..$^{20}$ According to data obtained in this study, an apparent shortage of physicians is identified in some specialties:

- 9901 internists (8/100 000 population) and 2671 cardiologists (2/100 000 population) were counted for the care of cardiovascular conditions, the second health problem of the country.

- There are 895 nephrologists, in spite of the increase renal problems has had.

- In spite of chronic obstructive pulmonary disease and lung cancer exhibiting increasing mortality rates, and their combination significantly surpassing ischemic heart disease as overall cause of death (16.7 \% versus $12.8 \%)$, ${ }^{21-23}$ one pulmonologist was found per 200000 population, a figure that is lower to that recommended by WHO (3.5 to 4 pulmonologists/100 000 population).

- In Mexico, older adults constitute a rapidly growing group (by 2050, it will account for $27 \%$ of the population). ${ }^{17}$ International standards recommend one geriatrist per 50000 population (hyyp://www. bgs.org.uk/) or one geriatrist per 2000 older adults (http://www.americangeriatrics.org/), which is a figure 15 -fold higher than that found in this study with 3 geriatrists per 100000 older adults.

In view of this scenario, first of all (prior to increasing the number of specialists, which would turn out to be expensive and wouldn't solve the underlying problem), implementing chronic-degenerative diseases early detection is required in order to prevent high-cost complications such as kidney failure or cardiovascular conditions. As we can observe, non-communicable diseases share 4 risk factors: tobacco consumption, excessive consumption of alcohol, unhealthy diet and physical inactivity; therefore, investing in aspects of promotion, minimization of exposure to risk factors, maximization of exposure to protecting factors, prevention and opportune detection, will set the bases to strengthen the change towards a primary health care model, where family doctors and primary care physicians play the most relevant role.

Health institutions urgently need to regulate productivity, improve the quality of care and establish a balance between the number of specialists and family doctors (according to the study, 14/100 000 population).
Data from the Ministry of Health show that productivity indicators of the last 10 years are considerably low among medical specialists (2 daily patient consultations per doctor), but comparatively high among primary care physicians and family doctors (13 daily patient consultations per doctor). ${ }^{24}$

Adequate communication is required between educational and health institutions since, currently, medical specialists provide care to the population by applying the clinical-curative method, establishing appropriate diagnosis and treatment for each case, but the rest of actions such as education, promotion of a healthy lifestyle, prevention, control and patient follow-up are carried out by health personnel trained on technical areas such as nursing, nutrition and psychology, among others. Therefore, it is crucial the transformation of a purely curative model into a preventive-curative one. In turn, reconsidering for some specialties, such as pediatrics and obstetrics and gynecology, a reduction in the number of working posts and increasing those of trained family doctors and primary care physicians. Finally, a rearrangement or an important increase of posts in specialties required to address emergent pathology is required, for which changes in admission requirements and duration of some specialties would be helpful.

According to data reported by CIFRHS in 2016, $75 \%$ of newly admitted residents are distributed in 6 main medical specialties: family medicine $(21.8 \%)$, internal medicine (13.5\%), anesthesiology (10.8\%), pediatrics (10.8\%), obstetrics and gynecology (9.9\%) and surgery (9.1\%) (http://www.cifrhs.salud.gob.mx/). Currently, within the UNAM Faculty of Medicine student population, these specialties represent $47 \%$ of students. ${ }^{6}$ The change in the way of admission, from indirect to direct, has previously solved the deficit in the number of aspirants in some specialties and, on the contrary, changing from direct to indirect admission has discouraged applicants' requests. ${ }^{25}$

Medical specialists' geographical distribution is rather inequitable, similar to what occurs in other countries, ${ }^{25-27}$ with a clear centralization and inequity in resource assignment for the training of specialists, which might be related to the following aspects:

- 9626 out of 26789 specialty students and 78 of 81 programs correspond to the UNAM Faculty of Medicine, ${ }^{6}$ the population of which was concentrated in Mexico City in 2016 (8644 out of 9626 students). Therefore, adequate planning of medical residence posts is required, which not necessarily implies increasing the number of posts 
in existing sites, but opening new specialty sites in different sates of the country.

- Lack of job offers, recognition and stimuli to graduate specialists to achieve their retention in cities of small and medium populations.

- Economic and social development concentration; i.e., in some states of the country there is lower per capita income, scarce or no access to quality basic education (thinking on graduate MS families), low availability of basic services (food, housing, etc.), lack of physical infrastructure for adequate practice of the profession and little or no possibilities to exercise private practice in conjunction with public practice of the profession. Therefore, creating conditions to make practice in semi-urban and rural areas more attractive to MS should be sought.

- There are states of the country with high rates of violence and scarce or no guarantee of safety. According to the National Medical Survey on Risk, Mexico City, Chihuahua, Coahuila, Hidalgo, Guerrero, Morelos, Nuevo León, Tamaulipas, Oaxaca and Veracruz are the federal territory entities with the highest reported violence. ${ }^{28}$

Another important aspect is medical work feminization, which constitutes a global phenomenon. In several OECD country members, the proportion of female doctors is almost equal to that of male doctors (46\% in the United Kingdom and $43 \%$ in France). ${ }^{4}$ Levinson and Lurie ${ }^{29}$ propose that females and males practice medicine differently; females can improve doctor-patient relationship and promote more teamwork owing to characteristics attributed to the female gender such as compassion, empathy, response capability to patient needs and communication skills. ${ }^{30,31}$ On the other hand, there are studies that refer that some patients prefer being attended to by a male in primary care services, which would generate problems in the search for opportune diagnosis and treatment. ${ }^{32-34}$ Internationally, there is a more ambivalent vision on the implications of the increasing number of women in medicine. On the one hand, they are willing to work in positions that are less well compensated and practice on primary care specialties, but, on the other, they prefer practicing in urban zones, probably owing to the need for more support to be able to combine maternity with their profession, avoid burnout and earn representation with the leadership and academics. $^{35}$

As regards gender distribution in Mexico, the population of women that are admitted to study medicine and that later study a medical residence is known to have gradually increased, but with differences in the male-to-female ratio: depending on the medical specialty; these differences have been suggested to be owing to the perception on the specialty lifestyle, with certain tendency being observed in males towards those with a non-controllable lifestyle: ${ }^{35}$ internal medicine, obstetrics and gynecology, orthopedics, general surgery and urology; and on females, towards those with controllable lifestyle: anesthesiology, dermatology, neurology, pathology, psychiatry and radiology.

In Mexico, not all physicians that graduate from training as residents get certified, and those who have been certified often do not get re-certified. Specialties such as urogynecology and reproductive biology have nearly $100 \%$ of MS with valid certification, whereas in general surgery, internal medicine, psychiatry and neuropatholony, there are less than $40 \%$. Such variation can be secondary to various factors:

- In internal medicine and general surgery it can be because specialists chose a second specialty or sub-specialty and did not re-certificate as internists or general surgeons anymore.

- In specialties with a high number of specialists with valid certification (gynecologic oncology, reproductive biology and urogynecology), probably due to their degree of over-specialization.

- Owing to the variations in promotion there are with regard to specialists' training and updating by each one of the specialty medical councils.

Among the strengths of the study we can mention that it is the first census of specialists performed based on total verifiable number of physicians rather than on a count taking occupied posts as reference, which generates duplicate data. ${ }^{14}$ It is the first study to establish a distribution by gender, specialty, state of the republic and certification validity of more than $90 \%$ of medical specialties available in the country.

The limitations lie in data availability: only specialists on whom there was information in any of the databases could be counted and located.

Prior to increasing the number of medical specialists, other actions should be carried out:

- Ensuring that higher education institutions graduate the personnel the population and health institutions require, both in quantity and educational approach (passing from a disease-centered to a preventive approach).

- Reinforce the importance of the primary care physician since, in contrast with medical 
specialists, Mexico City has the lowest percentage of primary care physicians. ${ }^{37}$

- Avoid physicians underuse by granting a space in the labor market to generalist physicians (family and general doctors) and specialists with equality of opportunities in different states of the country.

- Avoid medical over-specialization by means of regulation in educational programs (training approach, training requirements for admission and duration of each medical specialty).

- Limit the creation of new medical specialties that further fragment knowledge, which goes against global trend that points at an integrating and primary prevention model (which in the long term is less expensive than the current one).

- Medical work feminization has to be taken into account, since women need support and time in order to combine the practice of their profession with the care of children.

Therefore, articulating general medical training shift to a preventive paradigm, reduction in the number of graduates and creation of bodies that regulate their academic quality-, the labor market (both for specialist and general and family physicians, at all levels of care and states of the country) and the mixed epidemiological pattern -chronic-degenerative diseases together with diseases of social deprivation and poverty- is required, with the purpose for strategic planning of medical specialization to be carried out, the final goal of which should be sufficient and balanced distribution of human resources for health.

\section{Acknowledgements}

To doctor Onofre Muñoz-Hernández, chairman of CONACEM.

\section{References}

1. World Health Statistics 2015. Ginebra: World Health Organization; 2015

2. Situación de salud en las Américas, Indicadores Básicos 2015. USA Organización Panamericana de la Salud/Organización Mundial de la Salud; 2015.

3. Instituto Nacional de Estadística y Geografía. [Sitio web]. Sociedad. Cuadro resumen indicadores sociales. [Consultado $2017 \mathrm{Abr}$ 16]. Disponible en: http://www3.inegi.org.mx/sistemas/temas/default.aspx?s=est\&c=21702.

4. Organization for Economic Co-operation and Development. [Sitio web]. Health care resources. [Consultado 2017 Jun 8]. Disponible en: http:// stats.oecd.org/Index.aspx?DataSetCode=HEALTH_REAC\#.Data/

5. Comisión Interinstitucional para la Formación de Recursos Humanos para la Salud. [Sitio web]. XL Examen Nacional para Aspirantes a Residencias Médicas. [Consultado 2017 Jun 7]. Disponible en: http://www. cifrhs.salud.gob.mx/site1/enarm/2016.html.

6. Universidad Nacional Autónoma de México. Especializaciones 2018 México: Facultad de Medicina; 2017. [Consultado 2017 Jun 8]. Disponible en: https://escolares.facmed.unam.mx/doc/oficinaVirtual/alumnos/posgrado/instructivos/folletoBienvenidos2017.pdf
7. Zurn P, Dal Poz MR, Stilwell B, Adams O. Imbalance in the health workforce. Hum Resour Health. 2004;2:13.

8. Heinze G, Chapa GC, Carmona-Huerta J. Los especialistas en psiquiatría en México; año 2016. Salud Mental. 2016;39:69-76.

9. Proyecciones de la Población 2010-2050. México: Consejo Nacional de Población; 2017

10. Encuesta Nacional de Salud y Nutrición 2012. Resultados nacionales. México: Instituto Nacional de Salud Pública; 2012.

11. Espinoza-De-Los-Reyes SVM. Participación de la Academia Nacional de Medicina de México en la acreditación de las especialidades y la certificación de médicos especialistas. Gac Med Mex. 2014;150:227-234.

12. Frenk J, Chen L, Bhutta ZA, Cohen J, Crisp N, Evans T, et al. Health professionals for a new century: transforming education to strengthen health systems in an interdependent world. Lancet. 2010;376(9756): 1923-1958.

13. Secretaría de Educación Pública. [Sitio web]. Reconocimiento de Validez Oficial. [Consultado 2017 Jun 5]. Disponible en: http://www.sep.gob.mx/ es/sep1/Revoe\#.WhtWZvWcHmQ/

14. Fajardo DG, Santacruz VJ, Lavalle MC. La formación de médicos especialistas en México. Documento de postura. México: Academia Nacional de Medicina; 2015.

15. Miani C, Hinrichs S, Pitchforth E, Bienkowska-Gibbs T, Disbeschl S, Roland $\mathrm{M}$, et al. Best practice: Medical training from an international perspective. Rand Health Q. 2015:5:2.

16. Residencias médicas en América Latina. USA: Organización Panamericana de la Salud/Organización Mundial de la Salud; 2011.

17. Secretaría de Salud, Anuario de morbilidad 1984-2016. México: Dirección General de Epidemiología; 2017. [Consultado 2017 May 1]. Disponible en: https://www.gob.mx/salud/acciones-y-programas/anuarios-de-morbilidad-1984-2016.

18. Institute for Health Metrics and Evaluation. Data visualizations. [Consultado 2017 Jun 15]. Disponible en: http://www.healthdata.org/results/data-visualizations/

19. The World Bank. Fertility rate, total (births per woman). [Consultado 2017 Jun 19]. Disponible en: http://data.worldbank.org/indicator/SP.DYN. TFRT.IN/

20. Mental health atlas 2014. Ginebra: World Health Organization; 2015.

21. Sandoval-Gutiérrez JL, Sevilla RS, Bautista BB. Pulmonary diseases: First cause of mortality in the world. Chest. 2011;139:1550.

22. Organización Mundial de la Salud. [Sitio web]. ¿Cuál es la enfermedad que causa más muertes en el mundo? [Consultado 2017 Jun 15]. Disponible en: http://www.who.int/features/qa/18/es/

23. The World Bank. [Sitio web]. Datos, América Latina y el Caribe. [Consultado 2017 Jun 19]. Disponible en: http://datos.bancomundial.org/region/LAC/

24. Nigenda G, Muños JA. Projections of specialist physicians in Mexico: a key element in planning human resources for health. Human Resour Health. 2105;13:79.

25. Sepúlveda CC. Formación de especialistas médicos en Chile Rev Chil Cir. 2012;64:507.

26. Ministerio de Salud y Protección Social de la República de Colombia. Estudio de disponibilidad y distribución de la oferta de médicos especialistas, en servicios de alta y mediana complejidad en Colombia. Informe final. Colombia: Pontificia Universidad Javeriana/Centro de Protección para el Desarrollo; 2013.

27. Navarro PP, Contreras SAJ, Junco GMC, Sánchez VP, Sánchez-Cantalejo GC, Luque MN. Análisis de la distribución geográfica de médicos especialistas en la República Argentina. Argentina: OPS/OMS: 2015.

28. Rivera G. Tierras violentas sin médicos. Newsweek. 2017;21:8-13.

29. Levinson $\mathrm{W}$, Lurie $\mathrm{N}$. When most doctors are women: what lies ahead? Ann Intern Med. 2004;141:471-474.

30. Eagly AH, Johannesen-Schmidt MC, Van-Engen ML. Transformational, transactional, and laissez-faire leadership styles: a meta-analysis comparing women and men. Psychol Bull. 2003;129:569-591.

31. Roter DL, Hall JA., Aoki Y. Physician gender effects in medical communication: a meta-analytic review. JAMA. 2002;288:756-764.

32. Derose KP, Hays RD, McCaffrey DF, Baker DW. Does physician gender affect satisfaction of men and women visiting the emergency department? J Gen Intern Med. 2001;16:218-226.

33. Franks $P$, Bertakis KD. Physician gender, patient gender, and primary care. J Womens Health (Larchmt). 2003;12:73-80.

34. Pasko T, Smart DR. Physician characteristics and distribution in the U.S 2004-2005. USA: American Medical Association; 2004.

35. Spenny ML, Ellsbury KE. Perceptions of practice among rural family physicians-is there a gender difference? J Am Board Fam Pract. 2000;13:183-187.

36. Bickel J, Ruffin A. Gender-associated differences in matriculating and graduating medical students. Acad Med. 1995;70:552-559.

37. Nigenda G, Alcalde-Rabanal J, González-Robledo LM, Serván-Mori E García-Saiso S, Lozano R. Eficiencia de los recursos humanos en salud: una aproximación a su análisis en México. Salud Publica Mex. 2016;58:533-542 